https://helda.helsinki.fi

Diversity and ecological adaptations in Palaeogene lichens

\title{
Kaasalainen, Ulla
}

2017-04-24

Kaasalainen , U , Schmidt , A R \& Rikkinen , J 2017 , ' Diversity and ecological adaptations

in Palaeogene lichens ' , Nature plants , vol. 3 , no. 5 , 17049 . https://doi.org/10.1038/nplants.2017.49

http://hdl.handle.net/10138/309447

https://doi.org/10.1038/nplants.2017.49

unspecified

acceptedVersion

Downloaded from Helda, University of Helsinki institutional repository.

This is an electronic reprint of the original article.

This reprint may differ from the original in pagination and typographic detail.

Please cite the original version. 


\title{
Diversity and ecological adaptations in Palaeogene lichens
}

\author{
Ulla Kaasalainen ${ }^{1}$, Alexander R. Schmidt ${ }^{1}$ and Jouko Rikkinen ${ }^{2,3}$
}

\begin{abstract}
Lichens are highly specialized symbioses between heterotrophic fungi and photoautotrophic green algae or cyanobacteria. The mycobionts of many lichens produce morphologically complex thalli to house their photobionts. Lichens play important roles in ecosystems and have been used as indicators of environmental change. Here we report the finding of 152 new fossil lichens from European Palaeogene amber, and hence increase the total number of known fossil lichens from 15 to 167. Most of the fossils represent extant lineages of the Lecanoromycetes, an almost exclusively lichen-symbiotic class of Ascomycota. The fossil lichens show a wide diversity of morphological adaptations that attached epiphytic thalli to their substrates, helped to combine external water storage with effective gas exchange and facilitated the simultaneous reproduction and dispersal of both partners in symbiosis. The fossil thallus morphologies suggest that the climate of European Palaeogene amber forests was relatively humid and most likely temperate.
\end{abstract}

\section{Introduction}

Lichens are highly successful mutualistic symbioses, where a dominant fungal symbiont (mycobiont) hosts one or several taxa of phototrophic green algae and/or cyanobacteria (photobionts). A lichen-symbiotic lifestyle has evolved at least ten times in the Ascomycota and five times in the Basidiomycota ${ }^{1-3}$, with a vast majority of the over 18,000 currently known species of mycobionts being ascomycetes ${ }^{4}$. About $90 \%$ of these fungi establish symbioses with green algae $^{5}$.

Lichens are ecologically especially important in arctic and boreal ecosystems, but also in some temperate and Mediterranean forests and in tropical mountains. Their diversity and abundance tends to be highest in relatively humid climates, and many species thrive in moist mountain forests and in maritime regions of higher latitudes. Epiphytic lichens can be particularly 
important in intercepting atmospheric moisture, sequestering nutrients and providing habitat and food for animals ${ }^{6-8}$.

The morphology of lichens is highly specialized and astonishingly diverse ${ }^{9}$. Within a lichen thallus the photobionts provide photosynthate and in the case of cyanobacterial symbionts also fixed atmospheric nitrogen to the mycobiont. The mycobiont, in turn, provides water, facilitates gas exchange and provides a microenvironment that is relatively well protected against various abiotic and biotic stressors. Thallus structures are achieved through photobiontinduced developmental processes of the mycobiont, and almost identical thallus morphologies have often evolved in distantly related lichens through convergent evolution. Lichens show a variety of growth forms, from minute and structurally relatively simple crusts to large leaf-like (foliose) and shrubby (fruticose) forms, which include some of the most complex structures produced by Fungi ${ }^{9}$.

Fossilized lichens have appeared to be extremely rare, with only 15 unambiguous fossils described so far ${ }^{10-13}$. The oldest lichen fossils are known from the Early Devonian ${ }^{14-16}$, and one Mesozoic fossil has been described from the Early Cretaceous ${ }^{10}$. The first lichen fossils that can confidently be assigned to modern fungal lineages are from European Palaeogene amber, the fossilized resin of ancient conifers. Two possible lichens from Baltic amber were already published in the nineteenth century ${ }^{17-19}$, but since then only seven additional specimens have been reported from European ambers ${ }^{11,12,20-22}$. Five additional lichen fossils have been described from the Miocene ${ }^{13,23-25}$.

We screened hundreds of Baltic and Bitterfeld amber specimens and show that amber is an important, previously largely neglected source of fossil lichens. Our new material multiplies the number of known fossil lichens over tenfold and establishes fossil lichens as indicators of fossil forest ecosystems. Over 160 analysed lichen fossils provide the first overview of structural complexity in Palaeogene lichens. The fossils include many fine examples of morphological adaptation to the past forest environment of which some are missing or rare in the extant European lichen species.

\section{Results}

Our survey revealed 152 new lichen inclusions in 122 amber specimens, increasing the total number of known European Palaeogene lichen fossils to 161, of which 68 are preserved in Baltic 
amber and 93 in Bitterfeld amber (Supplementary Table 1). Most of the fossilized lichens represent extant lineages of the Lecanoromycetes (Ascomycota), with foliose species of the family Parmeliaceae being especially common (Figs 1-5). The most abundant genus is Anzia (Parmeliaceae), which comprises over $25 \%$ of all amber inclusions. The fossils also include several wellpreserved specimens of the extant genera Calicium (Caliciaceae) and Chaenotheca (Coniocybaceae). Owing to insufficient preservation of distinguishing morphological features most fossils can only be identified at the order or family level, and approximately $30 \%$ of the fossil lichens are not assigned to any specific lineage within the Ascomycota (Fig. 5a).

\section{Growth forms}

Foliose lichens. The amber specimens contain nearly 100 inclusions of foliose lichens (Fig. 5b). Foliose lichens have dorsiventral and flat thalli, which mainly grow horizontally and are often distinctly lobed (Fig. 1a-f). Foliose thalli can be either closely appressed (Fig. 1a) ormore loosely attached (Fig. 1C) to their substrate, and their morphology varies from rosette shaped (Fig. 1a) to clearly lobate, with narrow and linear (Fig. 1b-c) or wide and irregularly shaped lobes (Fig. 1d-f).

Fruticose lichens. The amber specimens contain 32 inclusions of fruticose lichens (Fig. 5b). Fruticose lichens produce shrubby (Fig. 1g-i) or pendulous (Fig. 1j-k) thalli with cylindrical or sometimes flattened lobes that are often attached to their substrate by a relatively narrow base. The fruticose fossils are either clearly erect (Fig. 1g-i), finely pendulous (Fig. 1k) or represent intermediate forms between the two main types (Fig. 1j).

Crustose lichens. The amber specimens include 16 fossils of crustose lichens (Fig. 5b). Many crustose lichens grow tightly appressed to or partly submerged into the substrate. Often the fruiting bodies are the most prominent and sometimes the only visible structures (Fig. 1l). One easily identified group of crustose taxa are the calicioid lichens, which produce characteristic pinlike fruiting bodies (Fig. 1n). Calicioid species have been preserved in 11 amber specimens (Fig. $5 b)$.

Squamulose lichens. The amber specimens include two lichen fossils with squamulose thalli (Figs $1 \mathrm{~m}$ and $5 \mathrm{~b})$. Squamulose lichens are typically small or minute and represent an intermediate growth form between foliose and crustose lichens. 
Cross-sections through several amber specimens demonstrate that the thalli of foliose, fruticose and squamulose lichen fossils are stratified and typically consist of a dense outer cortex and a loose internal medulla (Fig. 2j-1).

\section{Thallus anatomy}

Cortex. In stratified lichens the cortex forms the outermost, protective layer of the thallus (Fig. 3a), and the tightly packed cortical hyphae of the upper cortex are often visible in thallus crosssections (Fig. 2e,j-I). Many foliose lichens have a cortex also on the lower side, but squamulose lichens usually lack the ventral cortex (Fig. 2l).

Photobiont layer. In stratified lichen thalli the photobionts are usually situated in a distinct layer immediately beneath the cortex (Fig. 3b). In the three lichen fossils studied using scanning electron microscopy (SEM), the globular photobiont cells were small, varying from 3 to $7 \mu \mathrm{m}$, corresponding in size with the coccoid green algal photobionts of many extant lichens.

Medulla. In most stratified lichens the medulla occupies most of the thallus. It plays an important role in gas exchange and comprises very loosely organized hyphae (Figs $2 e$ and $3 c$ ) or more densely packed hyphae (Figs $2 \mathrm{j}-\mathrm{I}$ and $3 \mathrm{~d}$ ), which clearly differ from the strongly agglutinated cortex hyphae. As in modern lichens, the medulla of the fossils may entirely fill up the central parts of thallus (Fig. 2e,j,I) or encircle a hollow in the centre of the thallus lobe (Fig. 2k).

Cortical openings. Pseudocyphellae and other openings in the lichen cortex play a role in gas exchange by connecting medullary airspaces to the outside. Minute perforations are difficult to detect from amber inclusions but sometimes their presence is indicated by tiny air bubbles on the lichen surface. Additionally, obvious perforations were observed in 18 lichen fossils (Fig. 5b). These include relatively large pores through the upper cortex into the medulla or central hollow (Fig. 2f ) and cortex-lined sack-like depressions that opened to the lower surface of the thallus (Fig. $2 \mathrm{~d}, \mathrm{e}$ ).

Rhizines. Approximately 60 foliose lichen fossils have rhizines formed by agglutinated strands of fungal hyphae (Fig. 2a-d). The rhizines attach the lichens to their substrate and help to maintain a layer of air beneath the thallus (Fig. 2d), which is important for water absorption and/or gas 
exchange, and also facilitates periodic drying required for maintaining the physiological balance between lichen symbionts. The rhizines can be simple and robust (Fig. 2a,d), long and sparingly branched (Fig. 2b) or short and squarrose (Fig. 2c).

Spongiostratum. More than 40 foliose lichen fossils have a cushionlike spongiostratum on the lower surface of the thallus, formed by richly branched and anastomosing hyphae (Fig. 2b,i). The main function of the structure is in external water storage: the capillary spaces in the hyphal reticulum can quickly absorb and hold large quantities of water. Among extant lichens spongiostrata are produced by all species of Anzia and Pannoparmelia (Parmeliaceae), but not by any other lichens.

Cortical hairs. Cortical hairs can play a role in water absorption and influence the transmission of light through the cortex to the photobiont layer. Cortical hairs are present in three fossil lichens. One foliose lichen has fine, brown hairs on both sides of the thallus (Fig. 2g), but only the lower surface of another fossil is covered with a pale wooly tomentum (Fig. 2h).

\section{Reproductive structures}

Apothecia. Most lichen-forming fungi belong to the Ascomycota, and produce sexual spores in disc- or cup-shaped fruiting bodies (apothecia). Nearly 40 lichen fossils have preserved apothecia, mostly disc-shaped and often with well-developed margins (Figs $1 \mathrm{l}, 4 \mathrm{a}-\mathrm{d}$ and $5 \mathrm{c}$ ). The calicioid lichens produced well-stalked ascomata topped with a persistent spore mass (mazaedium; Fig. 1n).

Pycnidia. Many lichen-symbiotic ascomycetes produce asexual spores in minute spherical pycnidia. Some calicioid lichen fossils have pycnidia on the upper surface of their crustose thalli (Fig. $4 \mathrm{~g}$ ).

Soredia. In addition to or instead of fungal spores many lichens produce vegetative symbiotic propagules in which the symbiotic partners can disperse together. Eleven fossil lichens possess soredia (Fig. 5c), which are small groups of photobiont cells enveloped by a layer of fungal hyphae (Fig. 4e-f). They are typically produced in discrete structures (soralia) which represent openings from the photobiont layer through the otherwise solid cortex. Among the fossils, several foliose lichens had laminal soralia on the upper surfaces of thallus lobes. 
Isidia. Another common means of lichen-symbiotic dispersal is via isidia, small outgrowths of the thallus, which differ from soredia in having a well-developed cortex. Over 20 foliose lichen fossils had produced cylindrical to coralloid isidia either laminally or on the thallus margins (Figs $4 \mathrm{i}-\mathrm{j}$ and $5 c)$.

Lobules. Lobules are minute thallus lobes that share the same basic anatomy as the thallus, but are often constricted at the base and play a similar role in symbiotic dispersal as isidia and soredia. Typical lobules were observed in only one foliose lichen fossil, which had produced catenulate chains of lobules from thallus margins (Fig. 4h).

\section{Discussion}

Fossil lichens provide information about ancient environments and they have also been used to calibrate the evolution of the Ascomycota22,26-28. Especially in dating studies the cautious assignment of fragmentary fossils is crucial12. Many of the new lichen fossils can be confidently placed in the extant family Parmeliaceae, a predominately lichen-symbiotic lineage and one of the most diverse groups of Ascomycota ${ }^{28-30}$. Recent estimates of divergence times within the family place splits of some extant genera between the early Palaeocene and the late Oligocene, and a major radiation between the middle Eocene and the late Miocene ${ }^{28}$. The new fossils confirm that the diversification of parmelioid genera was well underway in the Palaeogene. Additionally, several species of Anzia must have been common in European amber forests, although the genus has since become extinct from the continent ${ }^{20,31-33}$. Also calicioid lichens were relatively numerous among the fossils. The genera Calicium and Chaenotheca are not closely related and represent different classes of Ascomycota, but have a very similar morphology and ecology. Both genera are represented by several inclusions, revealing that the convergence of calicioid fungi in Lecanoromycetes and Coniocybomycetes dates back at least to the Palaeogene. The additional presence of several other groups, including for example Pertusariales and Arthoniales highlights that the diversification of many lineages of lichenized Lecanoromycetes and other Ascomycota precedes the Palaeogene.

The morphological diversity of lichens in Palaeogene European amber forests is remarkable and includes examples of many features that were important for lichen adaptation. During the 
time-window of the European Palaeogene amber deposition 47-24 million years ago, the climate was in flux. The initially almost tropical conditions of central Europe gradually changed to subtropical and warm-temperate, and the amount of precipitation remained high ${ }^{34,35}$. In the early Eocene much of central Europe was covered by dense tropical forest, which is also the traditional conception of the Baltic amber forest. Recently this view has been challenged by several studies based on botanical inclusions in the amber ${ }^{36,37}$. The morphological adaptations observed in the fossil lichens are most consistent with a humid and moderately well-illuminated temperate forest.

The sheer number of preserved lichens and the diversity of different thallus morphologies reveal that Palaeogene amber forests provided favourable conditions for lichen growth. The high proportion of foliose and fruticose lichens among the fossils suggests that the epiphytes lived under a semi-open canopy rather than in deep shade, and many of their specific adaptations are most consistent with a humid or even wet forest habitat. It is important to note that no fragments of large and robust lichens have been preserved among the amber fossils. This may be partly explained by the higher preservation potential of small and fragile lichens, but also indicates that robust lichens were either absent or at least rare in the lower canopies of amber forests.

The primary production of a lichen thallus partly depends on the amount of photosynthetically active radiation it receives. The poikilohydric thallus must also be sufficiently hydrated for photosynthesis, but excessive moisture may easily lead to a situation where the amount of carbon fixed by lichen photobionts is not sufficient to counterbalance the high respiration losses of the hydrated mycobiont. Especially in robust lichens with large water holding capacities, prolonged water saturation may also hinder internal $\mathrm{CO}_{2}$ diffusion, further exacerbating the difficulties of maintaining positive net production under constantly wet conditions ${ }^{38-40}$. Thus, the general lack of robust thalli among the fossils indicates that the climate of amber forests favoured fragile lichens that were well adapted to maintain a very intricate balance between sufficient thallus hydration, photosynthesis and respiration.

Many morphological features preserved in the fossil lichens are beneficial for maintaining positive net production under humid and rather shady conditions. For example, the narrow and abundantly branched lobes of fruticose lichens and the thin layers of air between the rhizoids of many foliose lichens facilitate evaporation and gas exchange, and thus contribute to the maintenance of positive primary production. In addition, the loosely interwoven medulla and cortical perforations facilitate gas exchange, allowing lichens to maintain relatively high water contents without experiencing a concurrent depression in photosynthesis ${ }^{41-43}$. As a whole, many 
structural features in the Palaeogene fossil lichens helped to combine sufficient intrathalline water storage and maximal gas exchange efficiency, which is especially important in moist and shady forest habitats where epiphytic lichens regularly experience prolonged periods of thallus hydration.

The mycobionts of many lichens only reproduce by spores and must thus re-establish their symbiotic association with compatible photobionts at each reproductive cycle. As free-living photobionts may be difficult to find, many lichens also facilitate the simultaneous dispersal of the whole symbiotic consortium via symbiotic propagules, and sometimes photobiont sharing can lead to complex interactions between many different hosts ${ }^{44}$. As many Palaeogene lichen fossils preserve clear adaptations to symbiotic dispersal they unambiguously confirm that symbiotic dispersal has been an integral part of lichen ecology for at least tens of millions of years, and underline its potential importance in explaining present patterns in the population structure of lichen-symbiotic organisms ${ }^{44-49}$.

\section{Methods}

Origin and age of the fossil lichens. The new lichen fossils (Supplementary Table 1) are preserved inside 122 specimens of Baltic and Bitterfeld amber.

The majority of Baltic amber derives from the marine Blue Earth layer that is predominantly exposed on the Samland Peninsula northwest of Kaliningrad (Russia) and contiguous areas. Baltic amber is also frequently found washed ashore along the coast of the Baltic Sea (predominantly in the Baltic States, Poland, Denmark, Germany and in southern Sweden) and in adjacent areas ${ }^{50,51}$.

The absolute age of the Baltic amber is still under debate. Palynological data (pollen and dinoflagellates) suggest a late Eocene (late Priabonian) age (approximately 38-34 million years) of the Blue Earth ${ }^{50,52,53}$. Fewer amounts of amber also occur in older sediments including the Lower Blue Earth (Lutetian, middle Eocene) and even in younger horizons (Lower Gestreifter Sand, late Oligocene), leading to a possible age range of approximately 47 to 24 million years before present for all Baltic amber bearing strata $50,52-54$.

The frequently cited Lutetian age of the Blue Earth was suggested by Ritzkowski ${ }^{55}$ who dated glauconites deriving from the amber-bearing layer. However, Clauer et al. ${ }^{56}$ demonstrated that the applied dating methods can lead to older age estimates if the glauconites have been reworked or 
if non-glauconized detrital mica 'contaminated' the glauconite splits. Redeposition of the Baltic amber into the Blue Earth layer has also been suggested ${ }^{51}$. However, amber from the Blue Earth layer does not show typical signs of erosion which normally occur if amber has been re-worked, such as 'pebble-shaped' amber pieces or a dark oxidized crust. In contrast, the majority of amber from the Blue Earth is of a fresh lemon yellow colour and unoxidized ${ }^{57}$. However, the age estimate based on the palynomorphs still needs validation by an independent data set that is able to link the Baltic amber Lagerstätte to the global geologic time scale. In short, a late Eocene age of both the 'Baltic amber forest' and the main amber Lagerstätte is commonly assumed but not unambiguously proven.

Today, most Baltic amber is mined in the Jantarny mine at Samland Peninsula ( $54^{\circ} 52^{\prime} 06.00^{\prime \prime}$ $\left.\mathrm{N}, 19^{\circ} 58^{\prime} 20.00^{\prime \prime} \mathrm{E}\right)$ but given the wide occurrence of drifted Baltic amber along the Baltic Sea coast, it is impossible to trace the precise origin of every single amber specimen, especially from historic collections.

Bitterfeld amber derives from the Goitzsche open-cast mine near the city of Bitterfeld in central Germany $\left(51^{\circ} 37^{\prime} 20.00^{\prime \prime} N, 12^{\circ} 21^{\prime} 18.00^{\prime \prime} \mathrm{E}\right)$. The amber-bearing sediment of this locality is the Bernsteinschluff layer, located in the upper part of the Cottbus Formation, and it has been dated as late Oligocene with an absolute age of $25.3-23.8$ million years ${ }^{58,59}$. A notion that Bitterfeld amber represents redeposited Eocene Baltic amber is based on the significant proportion of identical arthropod morphologies in amber from both localities ${ }^{60}$. However, redeposition of Baltic amber is unlikely based on the reconstruction of the sedimentary environment of this amber deposit ${ }^{50}$. A local reworking of pre-Chattian amber, however, has not been dispelled so far (see refs ${ }^{61,62}$ for discussion). In any case, Bitterfeld amber is Palaeogene in age and its minimum age is approximately 24 million years. Bitterfeld amber is absent in historic amber collections as this deposit has only been mined from the 1970 s to the $1990 s^{63}$.

Despite the mentioned uncertainties in the temporal and spatial reconstruction of the amber deposition, the Palaeogene age of both ambers is certain, and according to the state of the art, the absolute age of the amber-bearing strata ranges between 47 and 24 million years.

Repository of the fossils. The repository of the specimens is shown in Supplementary Table 1. The specimens labelled by GZG (Geoscientific Collection of the University of Göttingen, Germany), MB (Museum für Naturkunde Berlin, Germany) and SMNS (Staatliches Museum für Naturkunde Stuttgart, Germany) are already part of museum collections. Three members of the Amber Study 
Group based at the Geological- Palaeontological Museum of the University of Hamburg (Germany) acquired specimens for their private collections and made them available for study and preparation. Specimens of these collections will be transferred to museum collections upon publication. Lichen fossils of the Carsten Gröhn Amber Collection will be deposited at the Geological-Palaeontological Museum of the University of Hamburg, those of the Heinrich Grabenhorst Amber Collection at the Geoscientific Collection of the University of Göttingen, and the final repository of the type specimens of the Jörg Wunderlich Amber Collection is the Senckenberg Museum in Frankfurt am Main.

Preparation, microscopy and illustration of the fossil lichens. For investigation, the amber pieces were ground and polished manually using a series of wet silicon carbide papers (grit from FEPA P 600 ( $25.8 \mu \mathrm{m}$ particle size) to 4,000 (5 $\mu \mathrm{m}$ particle size), Struers, Germany) to produce smooth surfaces for investigation. A fraction of a millimetre of amber was gradually removed from each amber piece, while frequently checking the preparation under a dissection microscope to ensure that the inclusions were not damaged (see ref. 64 for protocols).

Prepared amber specimens were mounted on a glass microscopic slide with the upper polished surface oriented horizontally. A drop of water was applied to the upper surface of the amber and covered with a $0.06-0.08 \mathrm{~mm}$ thickness glass coverslip (Menzel Inc.) to reduce light scattering from fine surface scratches and to improve optical resolution.

The amber inclusions were studied under a Carl Zeiss Stereo Discovery V8 dissection microscope and under a Carl Zeiss AxioScope A1 compound microscope, equipped with Canon 5D digital cameras. In most instances, incident and transmitted light were used simultaneously. For an enhanced illustration of the three-dimensional inclusions, the light-microscopical images are digitally stacked photomicrographic composites from up to 330 individual focal planes using the software package Helicon Focus 6.2.2.

For SEM, lichen inclusions from selected lichen specimens were partially exposed using a scalpel to remove the overlaying amber. Samples were transferred to a carbon-covered SEM mount using a wet hair from a superfine brush, sputtered with platinum/palladium $(2 \times 120 \mathrm{~s}$ at 20 mA, $10 \mathrm{~nm}$ coat thickness) using an Automatic Sputter Coater (Canemco Inc.) and examined under a field emission scanning-electron microscope (Carl Zeiss LEO 1530 Gemini).

After investigation, fragile amber pieces were fully embedded in a high-grade epoxy (EpoTek 301-2, Epoxy Technology) under vacuum (see ref. 65 for protocols) to ensure long-term 
preservation of the fossils. Data availability. All specimens are deposited in accessible repositories (Supplementary Table 1).

Data availability. All specimens are deposited in accessible repositories (Supplementary Table 1).

\section{Acknowledgements}

We thank V. Arnold (Heide), H. Grabenhorst (Wienhausen), C. Gröhn (Glinde), C. and H.W. Hoffeins (Hamburg), M. Kobbert (Münster), K. Nordman Ernst (Skagen), F.Witsch (Köln) and J. Wunderlich (Hirschberg) for providing specimens for this study, and G. Bechly (Stuttgart), A. Gehler (Göttingen) and C. Neumann (Berlin) for access to museum collections. D. Hause-Reitner (Göttingen) assisted with SEM imaging. This study was supported by the Alexander von Humboldt Foundation (grant to U.K.).

\section{References}

1. Lawrey, J. D., et al. High concentration of basidiolichens in a single family of agaricoid mushrooms (Basidiomycota: Agaricales: Hygrophoraceae). Mycol. Res. 113, 1154-1171 (2009).

2. Schoch, K. et al. The Ascomycota tree of life: a phylum-wide phylogeny clarifies the origin and evolution of fundamental reproductive and ecological traits. Syst. Biol. 58, 224-239 (2009).

3. Lücking, R., Dal-Forno, M. \& Sikaroodi, M. A single macrolichen constitutes hundreds of unrecognized species. Proc. Natl Acad. Sci. U. S. A. 111, 11091-11096 (2014).

4. Feuerer, T. \& Hawksworth, D. L. Biodiversity of lichens, including a world-wide analysis of checklist data based on Takhtajan's floristic regions. Biodivers. Conserv. 16, 85-98 (2007).

5. Rikkinen, J. Cyanolichens. Biodivers. Conserv. 24, 973-993 (2015).

6. Köhler, L., Hölscher, D., Bruijnzeel, L. A. \& Leuschner, C. Epiphyte biomass in Costa Rican oldgrowth and secondary montane rain forests and its hydrological significance. Tropical Montane Cloud Forests, eds Bruijnzeel, L. A., Scatena, F. N., Hamilton, L. S. (Cambridge University Press, Cambridge), pp. 67-76, (2010).

7. Elbert, W., et al. Contribution of cryptogamic covers to the global cycles of carbon and nitrogen. Nat. Geosci. 5, 459-462 (2012). 
8. Ellis, C. J. Lichen epiphyte diversity: a species, community and trait-based review. Perspect. Plant Ecol. Evol. Syst. 14, 131-152 (2012).

9. Honegger, R. The symbiotic phenotype of lichen-forming Ascomycetes and their endo- and epibionts. The Mycota IX: Fungal Associations ( $2^{\text {nd }}$ ed), ed. Hock, B. (Springer-Verlag, Berlin Heidelberg), pp. 287-339, (2012).

10. Matsunaga, K. K. S., Stockey, R. A. \& Tomescu, A. M. F. Honeggeriella complexa gen. et sp. nov., a heteromerous lichen from the Lower Cretaceous of Vancouver Island (British Columbia, Canada). Am. J. Bot. 100, 450-459 (2013).

11. Hartl, C., et al. Lichen preservation in amber: morphology, ultrastructure, chemofossils, and taphonomic alteration. Foss. Rec. 18, 127-135 (2015).

12. Kaasalainen, U., et al. The enigmatic fossil Alectoria succini Mägdefrau reconsidered, and new evidence of alectorioid morphologies in Paleogene lichens. PLOS ONE 10, e0129526 (2015).

13. Kaasalainen, U., et al. A Caribbean epiphyte community preserved in Miocene Dominican amber. Earth Env. Sci. T. R. So. (2017, in press).

14. Taylor, T. N., Hass, H. \& Kerp, H. A cyanolichen from the Lower Devonian Rhynie Chert. Am. J. Bot. 84, 992-1004 (1997).

15. Karatygin, I. V., Snigerevskaya, N. S. \& Vikulin, S. V. The most ancient terrestrial lichen Winfrenatia reticulata: A new find and new interpretation. Paleontol. J. 43, 107-114 (2009).

16. Honegger, R., Edwards, D. \& Axe, L. The earliest records of internally stratified cyanobacterial and algal lichens from the Lower Devonian of the Welsh Borderland. New Phytol. 197, 264275 (2013).

17. Goeppert, H. R. \& Berendt, G. C. Der Bernstein und die in ihm befindlichen Pflanzenreste der Vorwelt. (Nicolaische Buchhandlung, Berlin), (1845).

18. Caspary, R. \& Klebs, R. Die Flora des Bernsteins und anderer fossiler Harze des ostpreußischen Tertiars. Abhandlungen der Königlich Preußischen Geologischen Landesanstalt, Berlin, Neue Folge 4, 1-181 (1907).

19. Caspary, R. \& Klebs, R. Atlas von dreissig Tafeln zu der Abhandlung: Die Flora des Bernsteins und anderer fossiler Harze des ostpreußischen Tertiärs. Abhandlungen der Königlich Preußischen Geologischen Landesanstalt, Berlin (1907).

20. Rikkinen, J. \& Poinar, G. Fossilised Anzia (Lecanorales, lichenforming Ascomycota) from European Tertiary amber. Mycol. Res. 106, 984-990 (2002).

21. Rikkinen, J. Calicioid lichens from European Tertiary amber. Mycologia 95, 1032-1036 (2003). 
22. Beimforde, C. et al. Estimating the Phanerozoic history of the Ascomycota lineages: combining fossil and molecular data. Mol. Phylogenet. Evol. 78, 386-398 (2014).

23. Peterson, E. B. An overlooked fossil lichen (Lobariaceae). Lichenologist 32, 298-300 (2000).

24. Poinar, G. O., Jr., Peterson, E. B. \& Platt, J. L. Fossil Parmelia in New World amber. Lichenologist 32, 263-269 (2000).

25. Rikkinen, J. \& Poinar, G. A new species of Phyllopsora (Lecanorales, lichen-forming Ascomycota) from Dominican amber, with remarks on the fossil history of lichens. J. Exp. Bot. 59, 1007-1011 (2008).

26. Amo de Paz, G., Cubas, P., Divakar, P. K., Lumbsch, H. T. \& Crespo, A. Origin and Diversification of Major Clades in Parmelioid Lichens (Parmeliaceae, Ascomycota) during the Paleogene Inferred by Bayesian Analysis. PLoS ONE 12, e28161 (2011).

27. Prieto, M. \& Wedin, M. Dating the Diversification of the Major Lineages of Ascomycota (Fungi). PLOS ONE 8, e65576 (2013).

28. Divakar, P. K. et al. Evolution of complex symbiotic relationships in a morphologically derived family of lichen-forming fungi. New Phytol. 208, 1217-1226 (2015).

29. Crespo, A., et al. Phylogenetic generic classification of parmelioid lichens (Parmeliaceae, Ascomycota) based on molecular, morphological and chemical evidence. Taxon 59, 17351753 (2010).

30. Miadlikowska, J., et al. A multigene phylogenetic synthesis for the class Lecanoromycetes (Ascomycota): 1307 fungi representing 1139 infrageneric taxa, 317 genera and 66 families. Mol. Phylogenet. Evol. 79, 132- 168 (2014).

31. Yoshimura, I. Taxonomy and speciation of Anzia and Pannoparmelia. Bibl. Lichenol. 25, 185195 (1987).

32. Jayalal, U., et al. Anzia mahaeliyensis and Anzia flavotenuis, two new lichen species from Sri Lanka. Lichenologist 44, 381-389 (2012).

33. Wang, X. Y., et al. Taxonomic study of the genus Anzia (Lecanorales, lichenized Ascomycota) from Hengduan Mountains, China. Lichenologist 47, 99-115 (2015).

34. Mosbrugger, V., Utescher, T. \& Dilcher, D. L. Cenozoic continental climatic evolution of Central Europe. Proc. Natl Acad. Sci. U. S. A. 102, 14964-14969 (2005).

35. Collinson, M. E. Vegetational and floristic changes around the Eocene/Oligocene boundary in western and central Europe. Eocene-Oligocene Climatic and Biotic Evolution, eds Prothero, D. R., Berggren, W. A. (Princeton Univ. Press, Princeton), pp. 437-450 (1992). 
36. Kohlman-Adamska, A. A graphic reconstruction of an "amber" forest. The Amber Treasure Trove, Part 1, ed. Kosmowska-Ceranowicz, B. (Oficyna Wydawnicza Sadyba, Warsaw), pp. 1518 (2001).

37. Sadowski, E.-M., Schmidt, A. R., Seyfullah, L. J. \& Kunzmann, L. 2017. Conifers of the 'Baltic amber forest' and their palaeoecological significance. Stapfia (in press).

38. Kershaw, K. A. Physiological ecology of lichens. (Cambridge Univ. Press), (1985).

39. Rikkinen, J. Habitat shifts and morphological variation of Pseudevernia furfuracea along a topographic gradient. Symb. Bot. Ups. 32, 223-245 (1997).

40. Gauslaa, Y. \& Coxson, D. Interspecific and intraspecific variations in water storage in epiphytic old forest foliose lichens. Botany 89, 787-798 (2011).

41. Green, T. G. A. \& Lange, O. L. Ecophysiological adaptations of the lichen genera Pseudocyphellaria and Sticta to south temperate rainforests. Lichenologist 23, 267-282 (1991).

42. Valladares, F., Sancho, L. G. \& Ascaso, C. Water storage in the lichen family Umbilicariaceae. Bot. Acta 111, 99-107 (1997).

43. Lange, O. L., Büdel, B., Meyer, A., Zellner, H. \& Zotz, G. Lichen carbon gain under tropical conditions: water relations and $\mathrm{CO}_{2}$ exchange of Lobariaceae species of a lower montane rainforest in Panama. Lichenologist 36, 329-342 (2004).

44. Rikkinen, J. Molecular studies on cyanobacterial diversity in lichen symbioses. MycoKeys 6, 332 (2013).

45. Rikkinen, J. Ecological and evolutionary role of photobiont-mediated guilds in lichens. Symbiosis 34, 99-110 (2003).

46. Kaasalainen, U., et al. Cyanobacteria produce a high variety of hepatotoxic peptides in lichen symbiosis. Proc. Natl Acad. Sci. U. S. A. 109, 5886-5891 (2012).

47. Belinchón, R., Yahr, R. \& Ellis, C. J. Interactions among species with contrasting dispersal modes explain distributions for epiphytic lichens. Ecography 37, 1-7 (2014).

48. Dal Grande, F., et al. Molecular phylogeny and symbiotic selectivity of the green algal genus Dictyochloropsis s.l. (Trebouxiophyceae): a polyphyletic and widespread group forming photobiont-mediated guilds in the lichen family Lobariaceae. New Phytol. 202, 455-447 (2014).

49. Cornejo, C. \& Scheidegger, C. Cyanobacterial gardens: the liverwort Frullania asagrayana acts as a reservoir of lichen photobionts. Environ. Microbiol. Rep. 8, 352-357 (2016). 
50. Standke, G. Bitterfelder Bernstein gleich Baltischer Bernstein?-Eine geologische Raum-ZeitBetrachtung und genetische Schlußfolgerungen. Exkurs.f. und Veröfftl. DGG 236, 11-33 (2008).

51. Weitschat, W. \& Wichard, W. Atlas of plants and animals in Baltic amber (Verlag Dr. Friedrich Pfeil, München) (2010).

52. Kosmowska-Ceranowicz, B., Kohlman-Adamska, A. \& Grabowska, I. Erste Ergebnisse zur Lithologie und Palynologie der bernsteinführenden Sedimente im Tagebau Primorskoje. Metalla 66, 5-17 (1997).

53. Standke, G. Die Tertiärprofile der Samländischen Bernsteinküste bei Rauschen. Schriftenreihe für Geowissenschaften 7, 93-133 (1998).

54. Kasiński, J. R. \& Kramarska, R. Sedimentary environment of amber-bearing association along the polish-russian baltic coastline. Exkurs.f. und Veröfftl. DGG 236, 46-57 (2008).

55. Ritzkowski, S. K-Ar Altersbestimmungen der bernsteinführenden Sedimente des Samlandes (Paläogen, Bezirk Kaliningrad). Metalla 66, 19-24 (1997).

56. Clauer, N., Huggett, J., Hillier, S. How reliable is the K-Ar glauconite chronometer? A case study of Eocene sediments from the Isle of Wight. Clay Minerals 40, 167-176 (2005).

57. Grimaldi, D., Ross, A. Extraordinary Lagerstätten in Amber, with particular reference to the Cretaceous of Burma. Terrestrial Conservation Lagerstätten: Windows into the Evolution of Life on Land, eds Fraser, N.C., Sues, H.-D. (Dunedin Academic Press Ltd, Edinburgh), (2017, in press).

58. Blumenstengel, H. Zur Palynologie und Stratigraphie der Bitterfelder Bernsteinvorkommen (Tertiär). Exkurs.f. und Veröfftl. DGG 224, 17 (2004).

59. Knuth, G., Koch, T., Rappsilber, I. \& Volland, L. Concerning amber in the Bitterfeld regiongeologic and genetic aspects. Hallesches Jahrbuch für Geowissenschaften 24, 35-46 (2002).

60. Weitschat, W. Bitterfelder Bernstein - ein eozäner Bernstein auf miozäner Lagerstätte. Metalla 66, 71-84 (1997).

61. Dunlop, J.A., Bitterfeld amber. Biodiversity of Fossils in Amber, ed. Penney, D. (Siri Scientific Press, Manchester), pp. 57-68 (2010).

62. Wolfe, A. P., McKellar R. C., Tappert, R., Sodhi R. N. S. \& Muehlenbachs, K. Bitterfeld amber is not Baltic amber: Three geochemical tests and further constraints on the botanical affinities of succinate. Rev. Palaeobot. Palynol. 225, 21-32 (2016). 
63. Liehmann, G. Die maschinelle Gewinnung und Aufbereitung des Bernsteins im Tagebau Goitsche bei Bitterfeld - ein Erlebnisbericht. Exkurs.f. und Veröfftl. DGG 249, 24-30 (2013).

64. Schmidt, A. R., et al. Arthropods in amber from the Triassic Period. Proc. Natl. Acad. Sci. U. S. A. 109, 14796-14801 (2012).

65. Nascimbene, P. \& Silverstein, H. The preparation of fragile Cretaceous ambers for conservation and study of organismal inclusions. Studies on fossils in amber, with particular reference to the Cretaceous of New Jersey, Ed. Grimaldi, D. A. (Backhuys Publishers, Leiden), pp. 93-102 (2000). 


\section{FIGURES}
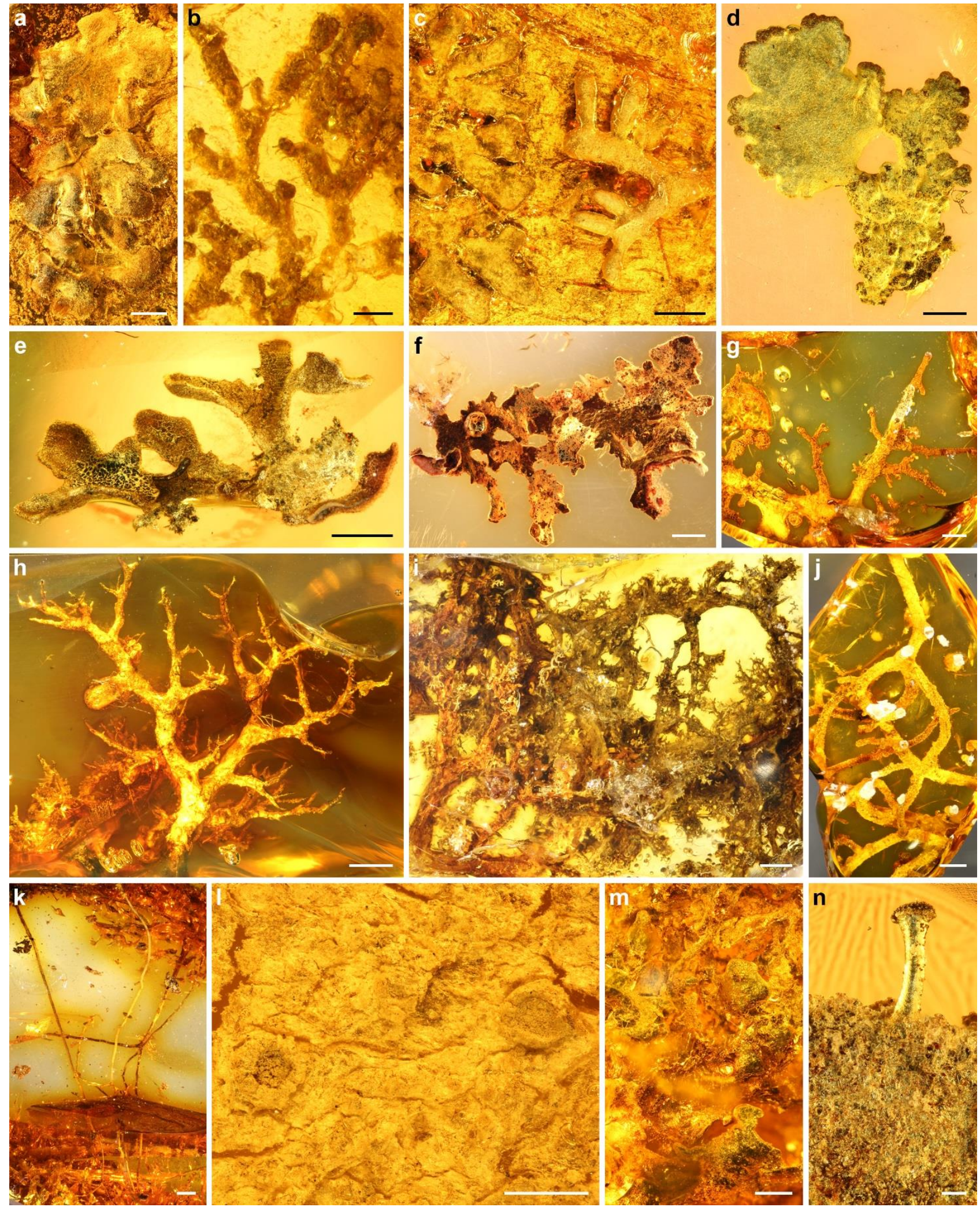

Figure 1. Growth forms of lichens preserved in Palaeogene amber. a, Foliose lichen tightly appressed at bark (GZG.BST.21910). b, Foliose lichen with narrow flattened thallus lobes (GZG.BST.21911). c, Foliose lichen with cylindrical thallus lobes (Grabenhorst Li-72). d, Possible phyllidium of a larger foliose lichen (Wunderlich F1107). e, Foliose lichen with palmate lobes 
(GZG.BST.21893). f, Foliose lichen with apically widening thallus lobes (Gröhn P 6406). g, Shrubby fruticose lichen with blunt branch tips (Gröhn P 6486). h, Shrubby fruticose lichen with acute branch tips (GZG.BST.21912). i, Densely branched fruticose lichen (GZG.BST.21913). j, Pendulous fruticose lichen with robust branches (Wunderlich F781). k, Pendulous fruticose lichen with fine branches (GZG.BST.21914). I, Crustose lichen with areolate thallus and two apothecia (GZG.BST.21915). m, Lichen squamules (GZG.BST.21916). $n$, Calicioid lichen with crustose thallus and single fruiting body with apical spore mass (MB.Pb.1979/838). Scale bars, $500 \mu \mathrm{m}$ in a-e,l,m; $1 \mathrm{~mm}$ in $\mathrm{f}-\mathrm{k}$; and $100 \mu \mathrm{m}$ in $\mathrm{n}$. 

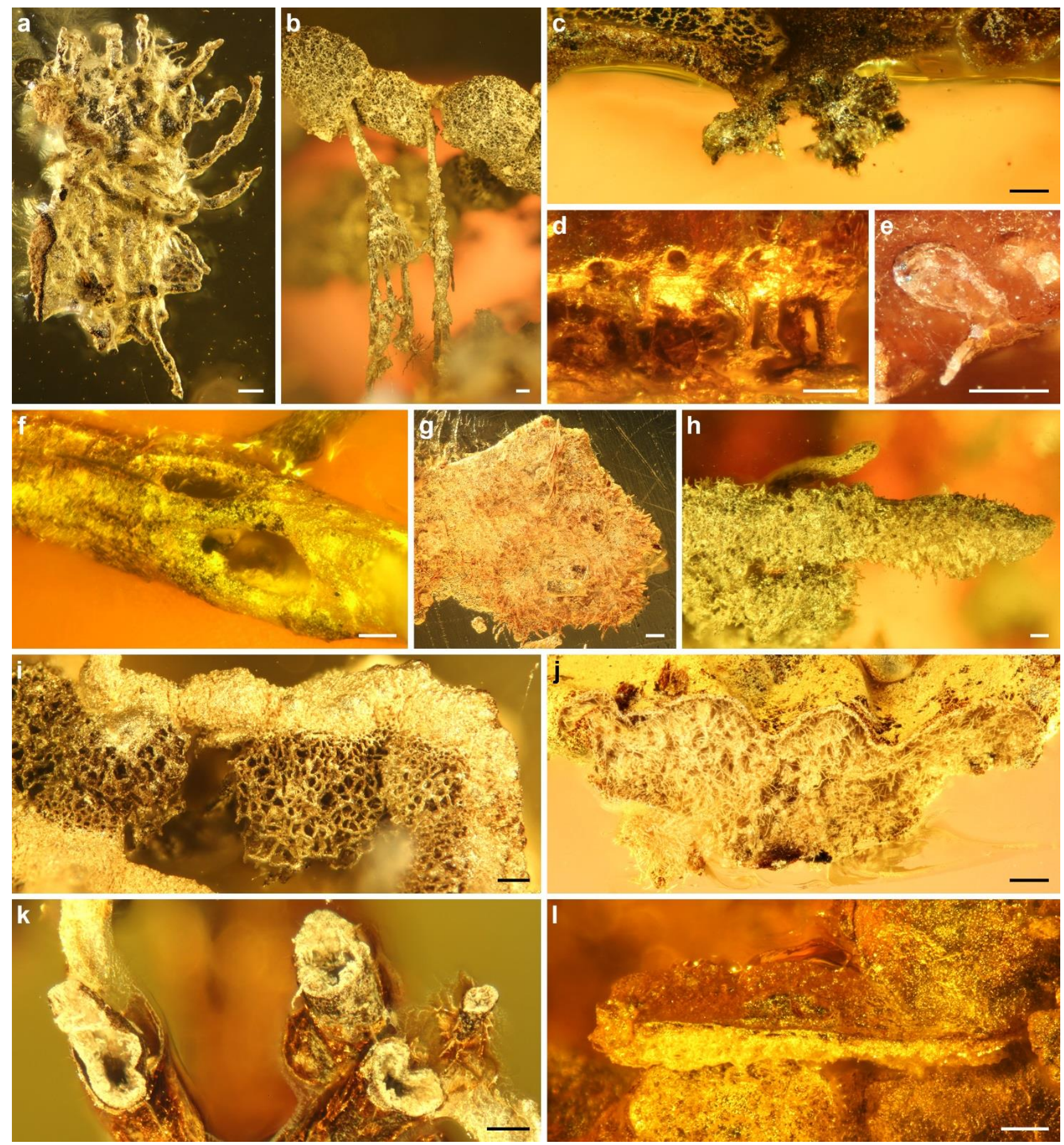

Figure 2. Morphology and anatomy of Palaeogene lichen thalli. a, Robust rhizines and thick cortex on the lower surface of a foliose lichen (GZG. BST.21917). b, Sparingly branching rhizines and spongiostratum on the lower surface of a foliose lichen (GZG.BST.21904). c, Short rhizine with squarrose anchoring tuft on the lower surface of a foliose lichen (GZG.BST.21893). $d$, Rhizines and large pores on the lower surface of a foliose lichen (GZG. BST.21918). e, Cross-section of a corticated sack-like depression embedded in a loose medulla (GZG.BST.21918). f, Large openings to a central hollow of a fruticose lichen (SMNS BB-2311-X). $g$, Translucent cortical hairs on the lower surface of a foliose lichen (Gröhn P 6406). h, Pale, wooly tomentum on the lower surface of a foliose lichen (Wunderlich F2799). i, Spongiostratum on the lower surface of a foliose lichen (GZG.BST.21904). j, Cross-section of a foliose lichen revealing a dense cortex and a loosely 
interwoven medulla (Wunderlich F1107). $k$, Cross-section of a fruticose lichen with hollow thallus lobes (GZG.BST.21919). I, Cross-section of a squamulose lichen with a relatively dense medulla and without a lower cortex (GZG.BST.21916). Scale bars, $100 \mu \mathrm{m}$.
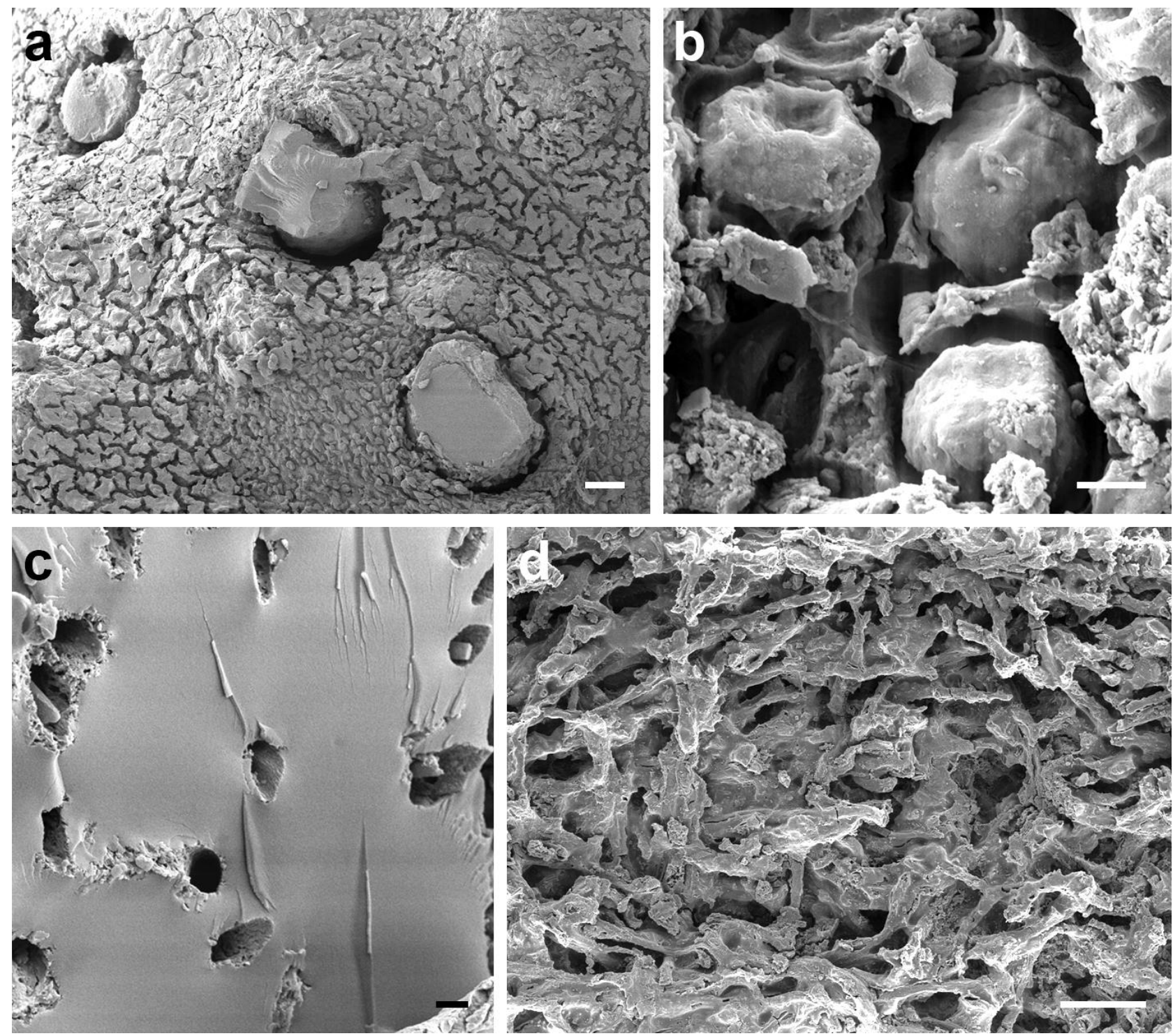

Figure 3. SEM images of lichens from Palaeogene amber. a, Fractured cortex and amber-filled pore openings on the lower side of a foliose lichen (GZG.BST.21920). b, Photobiont layer with three photobiont cells (Gröhn P 6406). c, Resin-filled very loose medulla of a foliose lichen; the position of degraded medullary hyphae is revealed by the tunnels in the amber (GZG.BST.21920). d, Partly resin-filled medulla of a foliose lichen (Gröhn P 6406). Scale bars, $20 \mu \mathrm{m}$ in a,d; and $2 \mu \mathrm{m}$ in b,c. 

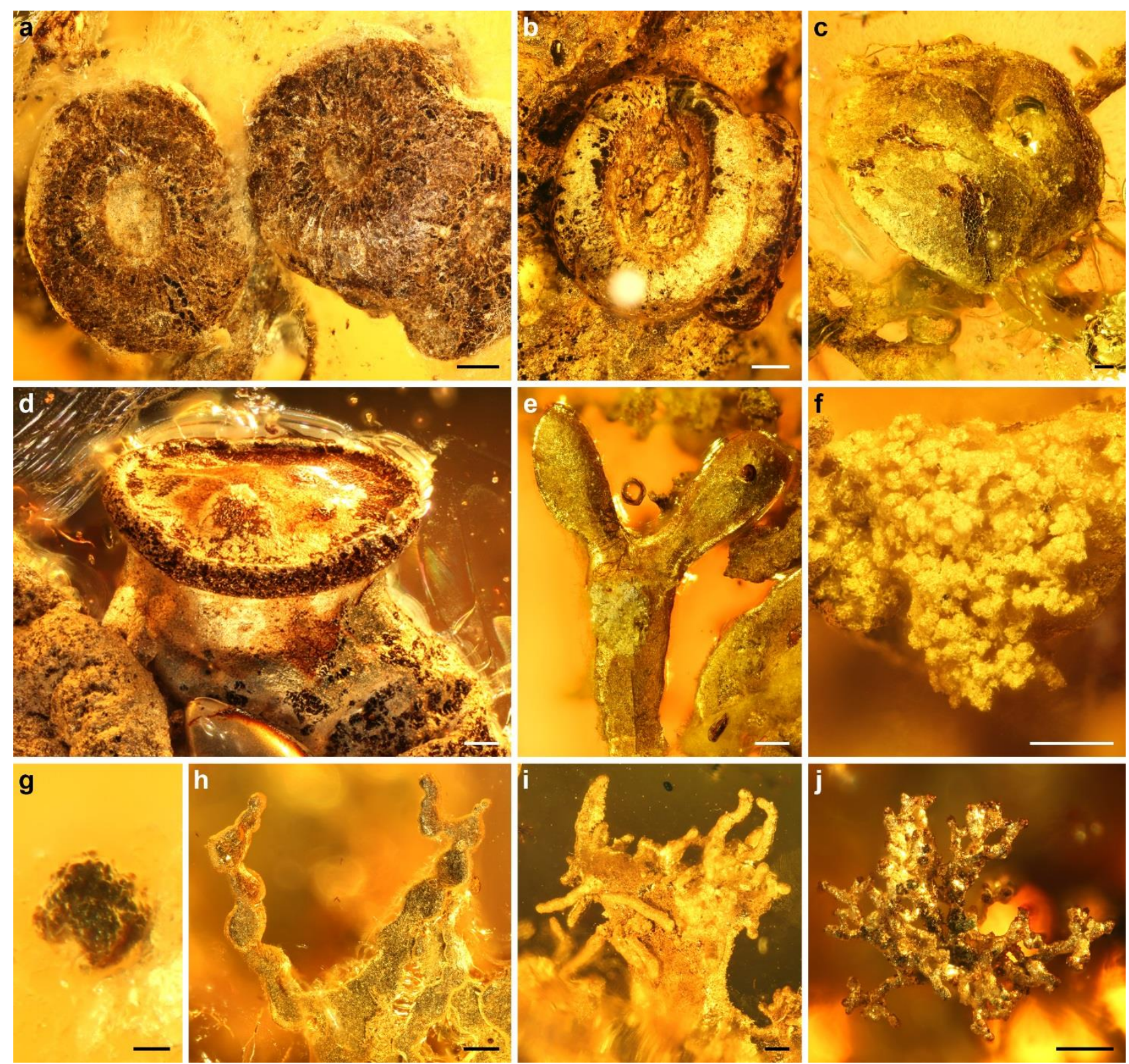

Figure 4. Reproductive structures of lichens from Palaeogene amber. $a, b$, Apothecia of a crustose lichen with thick margins (Grabenhorst Li-1, GZG. BST.27293). c, Stalked apothecium with poorly developed margin (Grabenhorst Li-120). d, Stalked apothecium of a foliose lichen with a flat disk and well-developed margin (Gröhn P 3576). e,f, Production of soredia from soralia on the upper surfaces of foliose lichens (Grabenhorst Li-72, Grabenhorst Li-71). g, Pycnidium exposed on a thallus of a Chaenotheca specimen (Gröhn P 5377). h, Catenulate lobules on the thallus margin of a foliose lichen (Gröhn P 3628). i, Long and cylindrical isidia on the upper surface and margins of a foliose lichen thallus (Wunderlich F2799). j, Coralloid isidia on branched apices of a fruticose lichen (GZG.BST.21913). Scale bars, $200 \mu \mathrm{m}$ in a-f,h-j; and $20 \mu \mathrm{m}$ in $\mathrm{g}$. 
a Affiliations

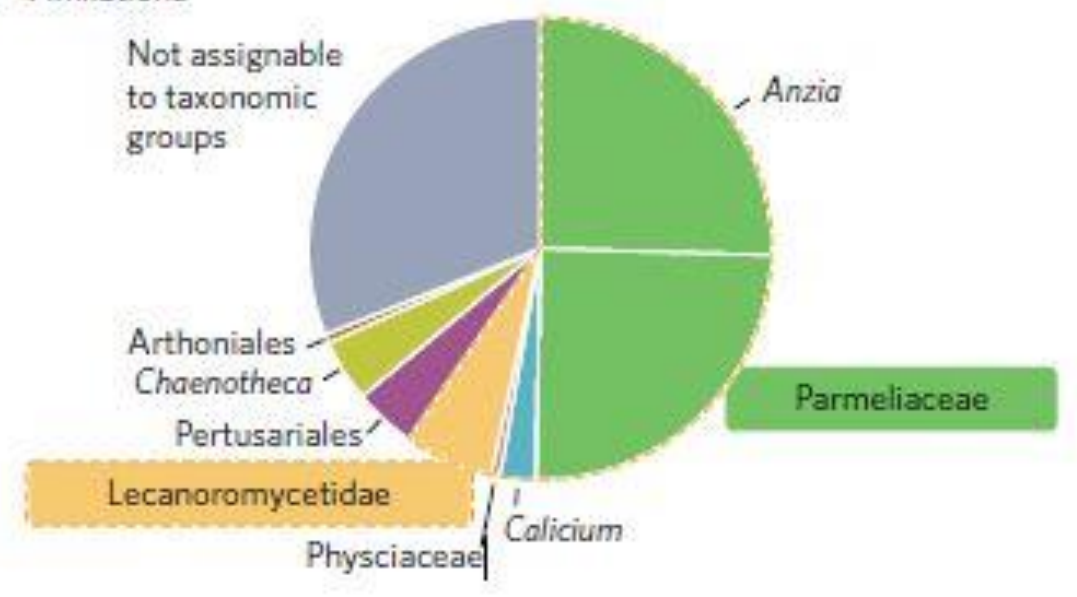

b Thallus morphology

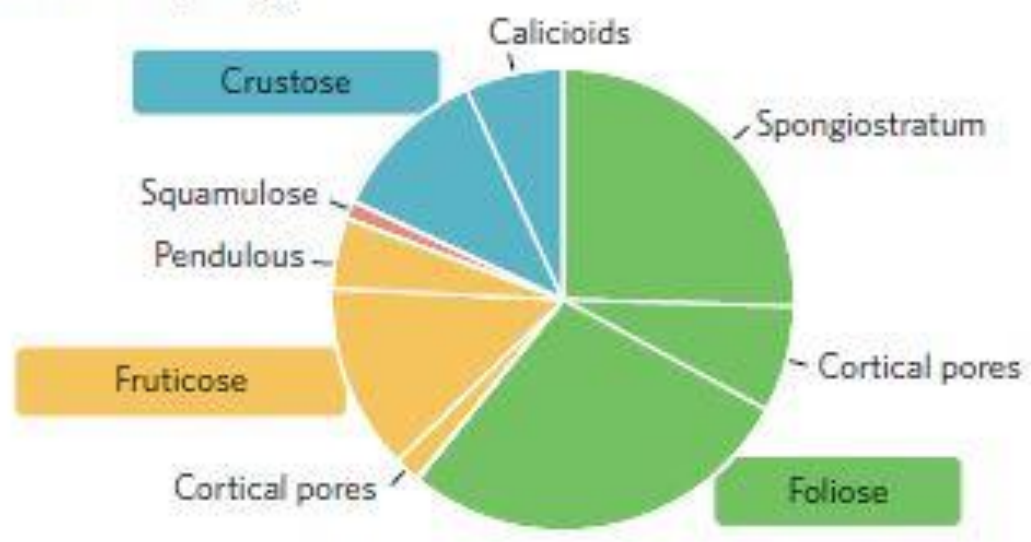

c Reproduction

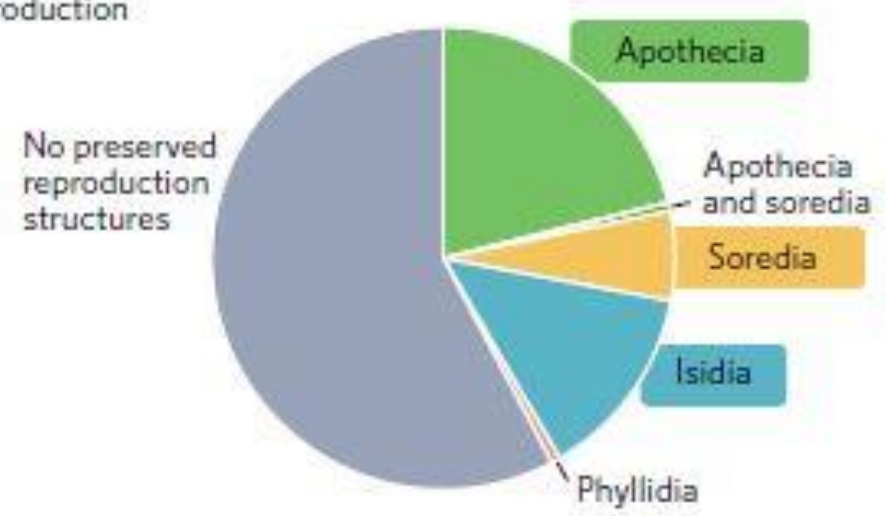

Figure 5. Taxonomic affiliation, thallus morphology and mode of reproduction of 161 lichen fossils preserved in Baltic and Bitterfeld amber (for details, see Supplementary Table 1). a, Many fossils can be assigned to extant orders (Pertusariales, and so on), families (Parmeliaceae, and so on) or even genera (Anzia, and so on), but the preservation of others does not allow reliable placement into any one taxonomic group. b, A majority of the fossils are foliose and fruticose lichens; see Figs 1 and 2 for examples of growth forms and thallus structures. c, Many fossils are very small and fragmentary, but a fair proportion of all fossils has preserved reproductive structures; see Fig. 4 for examples of such features. 